\title{
PENGARUH ARUS KAS OPERASI, UMUR PERUSAHAAN, DAN UKURAN PERUSAHAAN TERHADAP KINERJA PERUSAHAAN PERBANKAN YANG TERDAFTAR DI BURSA EFEK INDONESIA PERIODE 2011-2016
}

\author{
Oleh: \\ Aprilia Louise Cardilla1, Mochamad Muslih², Dedi Rianto Rahadi \\ STIE Tri Bhakti ${ }^{2}$, Universitas Presiden ${ }^{3}$

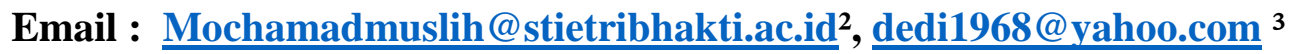

\begin{abstract}
ABSTRAK
Diantara 3 (tiga) arus kas yang terdapat dalam perusahaan, maka arus kas yang berasal dari operasi dianggap merupakan arus kas yang paling penting dalam perusahaan dan paling menentukan kesuksesan perusahaan dalam mencapai tujuan utamanya yaitu laba seoptimal mungkin. Tujuan penelitian ini adalah untuk mempelajari pengaruh arus kas yang berasal dari aktivitas operasi, ukuran perusahaan, dan umur perusahaan terhadap laba perusahaan. Metode penelitian yang digunakan adalah metode penelitian kuantitatip, dengan menggunakan metode ordinary least square. Unit analisisnya adalah perusahaan. Pemilihan sampel dilakukan secara purposive. Sampelnya adalah 12 perusahaan perbankan yang terdaftar di Bursa Effek Indonesia. Hasil penelitian menunjukan bahwa arus kas yang berasal dari aktivitas operasi dan ukuran perusahaan tidak berpengaruh signifikan pada laba perusahaan. Variabel umur perusahaan ternyata berpengaruh signifikan pada laba perusahaan, tetapi tandanya atau koefisiennya terbalik yaitu negatif. Ini berarti bahwa semakin tua umur perusahaan maka akan semakin menurun laba perusahaan.
\end{abstract}

Key Words: Laba, arus kas operasi, ukuran perusahaan, umur perusahaan.

\begin{abstract}
Among the 3 (three) cash flows contained in a company, the cash flows from operations are considered to be the most important cash flow in the company and most determine the success of the company in achieving its main objective, namely profit optimally. The purpose of this study was to study the effect of cash flows from operating activities, company size, and company age on company profits. The research method used is the quantitative research method, using the ordinary least square method. The unit of analysis is the company. Sample selection is done purposively. The sample is 12 banking companies listed on the Bursa Effek Indonesia.

The results showed that cash flows from operating activities and company size did not have a significant effect on corporate profits. The age variable of the company turned out to have a significant effect on company profits, but the sign or the coefficient was reversed. This means that the older the company age, the lower the company's profit.
\end{abstract}

Key Words: Profit, operating cash flow, company size, company age. 


\section{A. Pendahuluan}

Industri perbankan merupakan industri dengan kecenderungan yang semakin menguntungkan. Harga saham-saham perbankan cenderung naik dari waktu ke waktu. Hasil penelitian menunjukan bahwa pendorong utama naiknya harga saham adalah profitabilitas perusahaan. Muslih dan Nuryatno (2018) menyimpulkan dari hasil penelitiannya bahwa laba perusahaan berpengaruh sangat signifikan pada pergerakan harga saham. Hasil ini menunjukan bahwa laba perusahaan merupakan pertimbangan utama para calon investor dalam proses pengambilan keputusan pembelian saham

Pencapaian laba perusahaan dipengaruhi oleh banyak variabel dari fungsi manajerial seperti arus kas operasi, arus kas investasi, arus kas pendanaan, budaya perusahaan, umur perusahaan, ukuran perusahaan, partisipasi dalam penganggaran, kebijakan investasi, kebijakan pendanaan, dan jumlah anggaran. Dalam penelitian ini variabel yang akan diteliti adalah arus kas operasi dan 2 (dua) variabel tambahan yaitu umur perusahaan dan ukuran atau besaran perusahaan. Perbankan adalah industri yang terutama didasarkan pada kepercayaan nasabahnya. Karena itu kondisi likuiditas perusahaan sangat penting untuk dapat menjaga kepercayaan nasabahnya dan keberlangsungan usaha perusahaan. Salah satu pendukung unsur likuiditas adalah ketersediaan kas operasi perusahaan. Dengan demikian ketersediaan arus kas operasi berpengaruh pada kinerja perusahaan. Arus kas operasi dibutuhkan untuk melancarkan proses produksi dan meningkatkan penjualan.

Laporan arus kas adalah bagian dari laporan keuangan perusahaan yang dihasilkan pada suatu periode akuntansi yang menunjukkan aliran masuk dan keluar uang perusahaan. Arus kas operasi berasal dari sumber-sumber yang dapat diperbaharui kembali. Arus kas operasi berasal dari kegiatan operasi perusahaan, tetapi dapat digunakan untuk berbagai keperluan operasional perusahaan. Mulford (2005: 6) mengumpamakan arus kas operasi seperti mesin pencetak uang dalam perusahaan (Mulford, 2005:6).

Kas operasi berpengaruh terhadap laba perusahaan agar dapat mempertahankan kelangsungan perusahaan. Sunarti dan Adhi (2011) menyimpulkan dari hasil penelitiannya bahwa pada PT Indofood arus kas operasi berpengaruh pada kinerja perusahaan. Kroes dan Manikas (2014) menyimpulkan dari hasil penelitiannya bahwa terdapat hubungan antara strategi manajemen arus kas dengan kinerja perusahaan. Namun belum semua penelitian membuktikan adanya pengaruh 
hubungan antara arus kas operasi dengan kinerja perusahaan. Mun dan Yang (2015) menyimpulkan dari hasil penelitiannya bahwa sebagian besar perusahaan restoran mengelola modal kerjanya dengan ketat. Khususnya kira-kira separoh dari restoran tersebut memiliki modal kerja atau saldo kas negatif. Lebih lanjut Mun dan Yang menyatakan bahwa banyak perusahaan restoran sangat tergantung pada pemasok sehingga memiliki resiko operasional yang tinggi. Yensen at. al (2019) menyimpulkan dari hasil penelitiannya di Taiwan bahwa walaupun manajemen kas merupakan hal yang penting dalam perusahaan, namun arus kas dari operasi tidak dianggap sebagai signal yang menarik bagi perusahaan-perusahaan di Taiwan.

Ukuran perusahaan juga berpengaruh terhadap pencapaian kinerja perusahaan karena banyak hasil penelitian yang menunjukan pengaruh besaran perusahaan pada kinerja perusahaan. Ukuran perusahaan dapat ditentukan dari berbagai ukuran misalnya nilai aset, capaian penjualan, dan jumlah saham. Ukuran perusahaan merupakan tingkat atau ukuran besarnya perusahaan. Berbagai penelitian telah membuktikan adanya hubungan antara ukuran perusahaan dengan laba perusahaan. Penelitian menurut Alexander (2005) menyimpulkan dari hasil penelitiannya bahwa ada hubungan yang positif antara ukuran perusahaan dengan struktur modal. Amato (2007) juga membuktikan adanya pengaruh ukuran perusahaan terhadap tingkat laba perusahaan-perusahaan yang bergerak di bidang jasa keuangan. Lebih lanjut Gaur (2007) menyatakan terdapat hubungan yang positif antara ukuran perusahaan dengan laba perusahaan. Mesut Dogan (2013) menyimpulkan bahwa terdapat hubungan positif antara indikator-indikator ukuran dengan profitabilitas perusahaan. Chang (2013) menunjukan dari hasil studi empirisnya bahwa terdapat hubungan antara ukuran perusahaan dengan kinerja keuangan. Abiodun (2013) menyimpulkan bahwa terdapat hubungan positif antara ukuran perusahaan terhadap profitabilitas perusahaan pabrikasi di Nigeria. Namun belum semua penelitian membuktikan adanya hubungan positif yang signifikan antara umur perusahaan dengan kinerja perusahaan.

Umur perusahaan juga berpengaruh terhadap capaian kinerja perusahaan. Rossi (2016) telah melakukan studi literatur mengenai pengaruh umur perusahaan terhadap kinerja perusahaan dan menunjukan adanya variasi dalam hasil penelitian mengenai pengaruh umur perusahaan terhadap kinerja perusahaan. Selcuk (2016) menunjukan bahwa perusahaan-perusahaan yang masih muda menunjukan penurunan profitabilitas sejak awal tetapi mereka mungkin akan berlaba kembali pada usia tua. Loderer and Urs Waelchli (2010) menyimpulkan bahwa semakin tua perusahaan akan semakin menurun profitabilitasnya. Jadi berbeda hasilnya dengan hasil penelitian Selcuk. 
Dengan demikian masih terdapat inkonsistensi dalam hasil-hasil penelitian terdahulu mengenai pengaruh umur perusahaan terhadap kinerja perusahaan.

Berdasarkan pembahasan di atas, permasalahan dalam penelitian ini adalah apakah arus kas dari aktivitas operasi, ukuran perusahaan, dan umur perusahaan berpengaruh terhadap kinerja perusahaan. Tujuan penelitian ini adalah untuk membuktikan adanya pengaruh arus kas operasi terhadap kinerja perusahaan, membuktikan adanya pengaruh ukuran perusahaan terhadap kinerja perusahaan, dan membuktikan adanya pengaruh umur perusahaan terhadap kinerja perusahaan.

\section{B. Tinjauan Teoritis}

Grand theory dari penelitian ini adalah teori keagenan (agency theory). Pada dasarnya agency theory mengatur tentang hubungan antara pemilik dengan manajer. Hubungan antara pemilik dan manajer harus di atur sehingga manajer akan memutuskan dan bertindak untuk kepentingan pemilik atau pemegang saham. Bonazzi dan Islam (2007) juga mengatakan bahwa manajer mungkin tidak selalu bertindak untuk kepentingan terbaik pemegang saham bila pengendalian atas perusahaan terpisah dari kepemilikannya. Jensen and Meckling (1976) menyatakan bahwa organisasi dipandang sebagai nexus dan set kontrak diantara faktor-faktor produksi. Penelitian ini ingin membuktikan bahwa manajer menggunakan arus kas operasi, ukuran perusahaan, dan umur perusahaan untuk kepentingan terbaik perusahaan.

\section{Arus Kas Operasi}

Laporan arus kas adalah laporan yang menggambarkan kas masuk dan kas keluar pada suatu perusahaan selama satu periode. Laporan arus kas menyediakan informasi yang berguna mengenai kemampuan perusahaan untuk menghasilkan kas dari aktivitas operasi, mempertahankan dan memperluas kapasitas operasinya, memenuhi kewajiban keuangannya, dan membayar dividen. Laporan arus kas terdiri dari arus kas yang berasal dari aktivitas operasi, aktivitas investasi, dan aktivitas pendanaan..

Arus kas operasi merupakan arus kas yang bersumber dari kegiatan operasi perusahaan seperti misalnya arus kas dari penjualan barang dan/atau jasa perusahaan dan pembelian bahan baku. Arus kas yang berasal dari operasi perusahaan merupakan dana yang mendukung operasi-operasi perusahaan dalam rangka mencapai laba setinggi mungkin. Arus kas dari sumber lain yaitu dari sumber pendanaan dan investasi hanya dapat digunakan sesuai dengan tujuannya dan tidak 
dapat digunakan untuk operasi rutin perusahaan. Dengan demikian ketersediaan arus kas operasi dalam jumlah yang memadai dan dikelola dengan baik akan mendorong peningkatan laba perusahaan.

Fokus utama dari pelaporan keuangan perusahaan adalah laba dan informasi mengenai laba merupakan indikator yang baik untuk menentukan atau menilai kemampuan perusahaan dalam menghasilkan kas di masa datang. Namun, laporan arus kas tetap dibutuhkan karena kadangkala ukuran laba tidak menggambarkan kondisi perusahaan yang sesungguhnya. Laporan arus kas melaporkan ukuran arus kas untuk tiga aktivitas usaha yaitu operasi, investasi, dan pendanaan. Subramanyam (2013:92) menyatakan arus kas yang paling penting dari sebuah perusahaan sering kali berkaitan dengan kegiatan operasi.

Terdapat dua pilihan metode untuk melaporkan arus kas dari kegiatan operasi pada laporan arus kas yaitu metode langsung dan metode tidak langsung. Aktivitas operasi mempengaruhi laporan laba rugi, yang merupakan produk dari akuntansi akrual. Laporan arus kas melaporkan pengaruh kas dari aktivitas operasi. Aktivitas operasi juga memengaruhi aktiva lancar dan kewajiban lancar dalam neraca. Mulford dan Comiskey (2005:6) menyatakan bahwa uang tunai yang disediakan oleh kegiatan operasi adalah sumber utama dari arus kas yang berkelanjutan. Lebih lanjut Mulford dan Comiskey (2005:6) menyatakan bahwa arus kas operasi bagaikan mesin pencetak kas yang syah. Karena dihasilkan dari operasi perusahaan, maka tidak perlu dikembalikan kepada kreditur atau investor. Kroes dan Manikas (2014) menyimpulkan berdasarkan hasil penelitiannya bahwa terdapat hubungan antara perubahan arus kas operasi dengan perubahan kinerja perusahaan. Rohmawati dan Suhikmat (2017) menyimpulkan dari hasil penelitiannya di PT Unilever Tbk bahwa terdapat hubungan antara arus kas operasi dengan laba operasi. Wenas, Manossoh, dan Tirayoh (2017) juga menyimpulkan dari hasil penelitiannya bahwa arus kas operasi berpengaruh positif signifikan terhadap dividen kas.

Berdasarkan pembahasan tersebut di atas hipotesa penelitiannya adalah sebagai berikut.

\section{H1: Arus kas operasi berpengaruh positif pada kinerja perusahaan.}

\section{Ukuran Perusahaan}

Ukuran perusahaan merupakan tingkat besarnya perusahaan. Indikator ukuran perusahaan dapat dijabarkan dalam berbagai ukuran seperti misalnya nilai aset dan jumlah modal. Ukuran 
perusahaan menggambarkan besar kecilnya perusahaan yang ditunjukkan oleh total aktiva, jumlah penjualan, rata-rata total penjualan dan rata-rata total aktiva.

Ukuran perusahaan merupakan tolok ukur yang dapat digunakan untuk menentukan nilai perusahaan. Salah satu faktor dalam memilih perusahaan yang akan dijadikan pilihan untuk menanamkan dana oleh investor adalah dengan melihat ukuran dari suatu perusahaan. Dalam penelitian ini, ukuran perusahaan diukur dengan menggunakan seluruh aset yang dimiliki oleh perusahaan. Ukuran perusahaan dapat dibagi menjadi tiga yaitu perusahaan besar, menengah, dan kecil.

Berbagai penelitian telah membuktikan adanya hubungan antara ukuran perusahaan dengan laba perusahaan. Alexander (2005) menyimpulkan dari hasil penelitiannya bahwa ada hubungan yang positif antara ukuran perusahaan dengan struktur modal. Amato (2007) melakukan penelitian mengenai pengaruh ukuran perusahaan terhadap tingkat laba perusahaan-perusahaan yang bergerak di bidang jasa keuangan dengan menggunakan berbagai definisi ukuran perusahaan. Hasilnya adalah terdapat hubungan yang positif antara ukuran perusahaan dengan laba perusahaan. Gaur (2007) menyatakan dari hasil penelitiannya bahwa ukuran perusahaan berpengaruh pada laba perusahaan. Mesut Dogan (2013) juga menyimpulkan bahwa terdapat hubungan positif antara indikator-indikator ukuran dengan profitabilitas perusahaan. Jadi bila ukuran perusahaan meningkat maka kinerja juga akan meningkat. Chang (2013) menunjukan dari hasil studi empirisnya bahwa terdapat hubungan antara ukuran perusahaan dengan kinerja keuangan. Abiodun (2013) juga menunjukan bahwa terdapat hubungan positif antara ukuran perusahaan, dalam ukuran jumlah aset dan penjualan, terhadap profitabilitas perusahaan pabrikasi di Nigeria. Kumas (2014) melakukan penelitian pada pasar tenaga kerja Turki. Hasilnya dari studi empirisnya adalah terdapat hubungan antara ukuran perusahaan dengan kualifikasi pekerjaan. Jadi ada peran ukuran.

Berdasarkan pembahasan tersebut di atas, hipotesa penelitiannya adalah sebagai berikut.

\section{H2 : Ukuran perusahaan berpengaruh positif terhadap kinerja perusahaan.}

\section{Umur Perusahaan}

Umur perusahaan juga berpengaruh terhadap kinerja perusahaan. Secara logika, semakin tua umur perusahaan akan semakin besar kemampuan perusahaan untuk mencapai kinerja yang telah 
ditetapkan. Umur perusahaan merupakan waktu yang sudah dicapai sejak awal berdiri hingga waktu yang tak terbatas.

Telah banyak penelitian terdahulu mengenai pengaruh umur perusahaan terhadap kinerja perusahaan. Rossi (2016) telah melakukan studi literatur mengenai pengaruh umur perusahaan terhadap kinerja perusahaan. Hasil penelitiannya menunjukan bahwa studi terdahulu masih menunjukan adanya variasi dalam hasil penelitian mengenai pengaruh umur perusahaan terhadap kinerja perusahaan. Sebagian penelitian mengatakan adanya pengaruh umur perusahaan terhadap kinerja perusahaan, sebagian lagi menunjukan tidak adanya pengaruh umur perusahaan terhadap kinerja perusahaan. Selcuk (2016) menyimpulkan dari hasil penelitiannya bahwa perusahaanperusahaan yang masih muda menunjukan penurunan profitabilitas sejak awal tetapi mereka mungkin akan berlaba kembali pada usia tua. Ilaboya dan Ohiokha (2016) juga menyimpulkan bahwa terdapat hubungan positif yang signifikan antara umur perusahaan dengan profitabilitas. Berdasarkan hasil pembahasan tersebut di atas maka hipotesanya adalah sebagai berikut.

H3 : Umur perusahaan berpengaruh positif terhadap kinerja perusahaan.

\section{Metode Penelitian}

Penelitian ini menggunakan metode penelitian kuantitatif. Pengolahannya dengan ordinary least squares $(O L S)$, dengan menggunakan program Eviews 9.

Model penelitiannya adalah $\mathrm{y}=\mathrm{a}+\mathrm{b} 1 \mathrm{x} 1+\mathrm{b} 2 \times 2+\mathrm{b} 3 \times 3+\mu$ dimana $\mathrm{y}=$ kinerja perusahaan; $\mathrm{x} 1=$ arus kas operasi; $\mathrm{x} 2$ = ukuran perusahaan; dan $\mathrm{x} 3=$ umur perusahaan.

Unit analisisnya adalah perusahaan. Populasi dari penelitian ini adalah data laba, arus kas operasi, ukuran perusahaan, dan umur perusahaan dari 12 (dua belas) perusahaan perbankan yang terdaftar di Bursa Efek Indonesia tahun 2011 sampai dengan 2016.

Penelitian ini menggunakan data sekunder, yaitu data yang tersedia di Laporan Tahunan (annual report). Pemilihan data dilakukan secara purposive, yang terdiri atas data laba perusahaan, operating cash flow, besaran perusahaan (firm size), dan umur perusahaan dari perusahaanperusahaan perbankan yang terdaftar di Bursa Efek Indonesia tahun 2011-2016. Variabel dari penelitian ini dan pengukurannya adalah sebagai berikut. Proksi dari kinerja perusahaan dalam penelitian ini adalah laba tahun berjalan, diambil dari Laporan Keuangan audited perusahaan perbankan yang terdaftar di Bursa Efek Indonesia. Umur perusahaan diukur berdasarkan umur perusahaan sejak perusahaan didirikan sampai dengan tahun pengukuran. Pengukuran disajikan 
dalam bulan. Arus kas operasi diukur berdasarkan saldo operating cashflow awal periode, yang disajikan pada Laporan Keuangan perbankan yang terdaftar di Bursa Efek Indonesia. Ukuran perusahaan diukur berdasarkan nilai aset perusahaan perbankan yang menjadi sampel.

Analisis data akan dilakukan dengan melakukan uji asumsi klasik, uji koefisien determinasi, dan uji korelasi. Uji asumsi klasik terdiri atas uji normalitas data, uji multikolinearitas, uji heterokedastisitas, dan uji serial correlation. Keempat uji tersebut akan disajikan di bawah ini. Uji normalitas data adalah untuk menentukan apakah datanya normal atau tidak sehingga layak diregress dan dijadikan dasar pengambilan simpulan dan keputusan. Indikator normalitas data terutama dengan indikator Jarqua Berra. Nilai absolut Jarque-Bera menjadi ukuran penyimpangan distribusi dari normal. Jadi ambang batas atas nilai Jarque Bera adalah 2. Bila nilainya di atas 2 maka berarti penyimpangan distribusi tidak normal.

Uji multikolinearitas untuk menentukan adanya hubungan antara variabel independen. Uji multikolonieritas menguji apakah antar variabel yang terdapat dalam model regresi memiliki hubungan korelasi. Jika variabel independen saling berkorelasi, maka variabel-variabel ini tidak ortogonal. Variabel ortogonal adalah variabel independen yang nilai korelasi antar sesama variabel independen sama dengan nol (Ghozali, 2009). Petunjuknya terutama dengan indikator atau nilai Durbin Watson Statistics. Adanya multikolinearitas juga bisa dideteksi dengan Variance Inflation Factor (VIF). Bila nilai Centered VIF <10 maka berarti tidak ada multikor.

Uji heteroskedastisitas untuk menentukan probable density of $\mu$. Uji Heteroskedastisitas bertujuan untuk menguji apakah di dalam model regresi terjadi ketidaksamaan varians dari residual satu pengamatan ke pengamatan yang lain. Apabila varians dari residual satu pengamatan ke pengamatan lain tetap, maka dapat disebut homoskedastisitas dan jika berbeda disebut heteroskedastisitas. Model regresi yang baik adalah yang homoskedastisitas atau tidak terjadi heteroskedastisitas (Ghozali, 2009). Bila indikator DW tidak melebihi 2 maka tidak terdapat heterokedastisitas.

Autokorelasi merupakan kolerasi antara anggota observasi yang disusun menurut waktu atau tempat. Model regresi yang baik seharusnya tidak autokorelasi. Metode pengujian menggunakan uji Durbin-Watson.

Uji koefisien diterminasi dalam regresi untuk mengetahui besar perubahan variabel Y yang dapat dijelaskan oleh variabel X (goodness of fit). Uji ini terutama ditunjukan dengan indikator 
R2. Menurut Ghazali (2013: 59) koefisien determinasi pada intinya mengukur seberapa jauh kemampuan model dalam menerangkan variasi variabel independent.

Uji F untuk mengetahui pengaruh secara keseluruhan (simultan) variabel independen terhadap variabel dependennya.

Uji t untuk mengetahui pengaruh parsial antara satu variabel independen dengan variabel dependennya.

\section{Hasil Penelitian dan Pembahasan}

Penelitian ini menggunakan data dari laporan keuangan perusahaan perbankan tahun 2011-2016, pada perusahaan yang terdaftar di Bursa Efek Indonesia (BEI). Penelitian ini menggunakan sampel sebanyak 12 (dua belas) perusahaan. Dengan demikian data yang digunakan merupakan data panel dari beberapa perusahaan perbankan untuk beberapa tahun pengamatan.

\section{Hasil Penelitian}

Hasil normality test atas data penelitian menunjukan hasil sebagai berikut

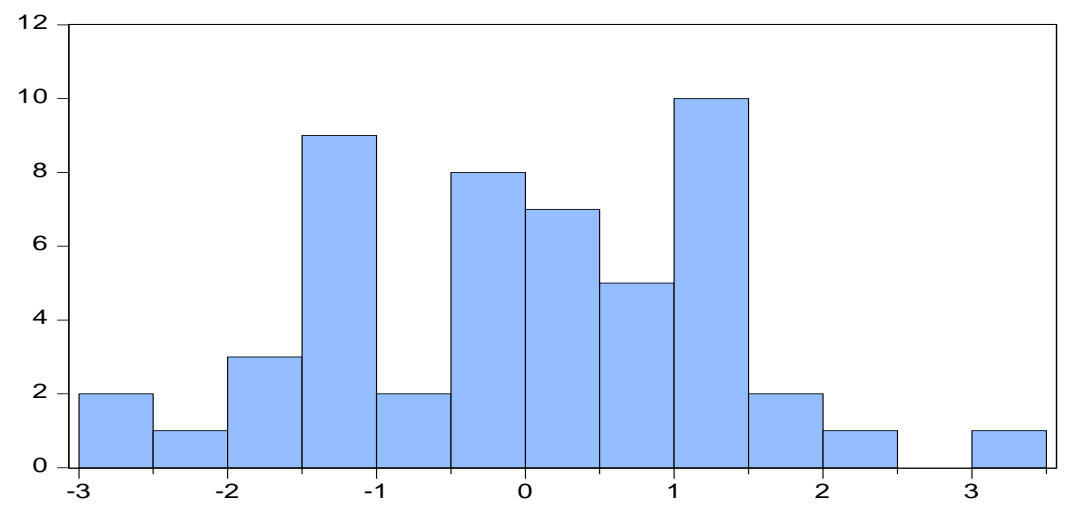

\begin{tabular}{|lr|}
\hline \multicolumn{2}{|l|}{ Series: Residuals } \\
Sample 170 \\
Observations & \multicolumn{1}{|l|}{51} \\
Mean & $9.38 \mathrm{e}-16$ \\
Median & 0.129625 \\
Maximum & 3.001905 \\
Minimum & -2.765089 \\
Std. Dev. & 1.319986 \\
Skewness & -0.063186 \\
Kurtosis & 2.341687 \\
& \\
Jarque-Bera & 0.954860 \\
Probability & 0.620376 \\
\hline
\end{tabular}

(Sumber: Data diolah)

Berdasarkan uji normalitas yang telah dilakukan dengan menggunakan program eviews menunjukan hasil seperti yang ditunjukkan pada tabel diatas. Dapat di lihat bahwa hasil uji normalitas menunjukan nilai skewness $-0,06$ dan kurtosis 2,34. Nilai maksimum skewness adalah 3 dan maksimum kurtosis juga 3. Berarti distribusi residual tidak menceng dan tidak mancung. Indikator Jarqua Bera juga menunjukan nilai 0,95. Nilai maksimum indikator JarquaBera adalah 2. Berarti distribusi residual normal.

Uji multikolinearitas menunjukan hasil sebagai berikut : 
Date: $07 / 31 / 18$ Time: $15: 28$

Variance Inflation Factors

Sample: 172

Included observations: 51

\begin{tabular}{llll}
\hline \hline & \multicolumn{2}{l}{ Coefficient } & \multicolumn{2}{l}{ Uncentered Centered } \\
Variable & Variance & VIF & VIF \\
\hline \hline C & 3.890883 & 107.0552 & NA \\
KAS & 0.008867 & 54.63187 & 1.447738 \\
SIZE & 0.025879 & 103.0005 & 1.608370 \\
AGE & 0.078869 & 76.84177 & 1.135918
\end{tabular}

Berdasarkan uji multikolinearitas yang telah dilakukan seperti yang ditunjukkan pada tabel diatas, diperoleh hasil bahwa Centered VIF untuk variable kas 1,45, variable size 1,61, dan variable age 1,14 . Semuanya lebih kecil dari 10 . Berarti tidak ada multikolinearitas dalam model penelitian. Uji heteroskedastisitas menunjukan hasil sebagai berikut.

Dependent Variable: LABA

Method: Least Squares

Sample (adjusted): 170

Included observations: 51 after adjustments

\begin{tabular}{lllll}
\hline \hline Variable & Coefficient & Std. Error & t-Statistic & Prob. \\
\hline \hline C & 10.77803 & 1.972532 & 5.464059 & 0.0000 \\
KAS & 0.047962 & 0.094165 & 0.509342 & 0.6129 \\
SIZE & 0.215881 & 0.160868 & 1.341974 & 0.1861 \\
AGE & -0.919487 & 0.280836 & -3.274110 & 0.0020 \\
\hline \hline & & & & \\
R-squared & 0.208984 & Mean dependent var & 8.631317 \\
Adjusted R-squared & 0.158493 & S.D. dependent var & 1.484145 \\
S.E. of regression & 1.361461 & Akaike info criterion & 3.530179 \\
Sum squared resid & 87.11809 & Schwarz criterion & 3.681695 \\
Log likelihood & -86.01956 & Hannan-Quinn criter. & 3.588077 \\
F-statistic & 4.139075 & Durbin-Watson stat & 0.287210 \\
Prob(F-statistic) & 0.011031 & & &
\end{tabular}


Sesuai dengan hasil yang ditunjukkan dalam tabel diatas, dapat di lihat bahwa nilai durbinwatson statistic 0,29. Untuk syarat tidak terjadinya heteroskedastisitas nilai durbin-watson maksimum adalah 2. Berarti tidak ada heteroskedastisitas dalam model penelitian. Dari table di atas dapat di lihat bahwa nilai indikator durbin Watson 0,29. Untuk tidak terjadinya serial correlation, nilai durbin watson maksimum adalah 4. Berarti tidak terjadi serial correlation dalam model penelitian.

Uji regresi yang dilakukan dengan program eviews 9 menunjukan hasil sebagai berikut:

Variabel ukuran perusahaan ternyata juga tidak berpengaruh terhadap laba perusahaan. Besaran perusahaan ternyata belum tentu menambah kapasitas atau kemampuan perusahaan untuk memperoleh laba. Ini sesuai dengan hasil penelitian Pomar (2016) bahwa enterpreneural orientation merupakan kondisi yang cukup untuk adanya kinerja pada perusahaan-perusahaan jasa olah raga Spanyol yang kecil, bukan pada perusahaan-perusahaan besar. Dengan demikian perusahaan yang kecil justru akan menjadikan operasi-operasi perusahaan menjadi lebih efisien. Umur perusahaan ternyata berpengaruh signifikan terhadap kinerja perusahaan. Tapi tandanya menjadi negatif. Artinya semakin tua umur perusahaan, maka labanya akan semakin menurun. Loderer and Urs Waelchli (2010) mengatakan bahwa semakin tua perusahaan akan semakin menurun profitabilitasnya karena semakin tua perusahaan tata kelolanya akan semakin menurun, direksi menjadi lebih besar, dan semakin tingginya gaji CEO dalam perusahaan-perusahaan yang semakin besar. Dengan demikian perusahaan harus selalu meningkatkan tata kelolanya sehingga faktor umur tidak menghambat kemajuan perusahaan. .Demikian juga Rossi (2016) menyimpulkan dari studi literaturnya bahwa ada pengaruh umur perusahaan terhadap kinerja perusahaan, namun sebagian lagi menunjukan tidak adanya pengaruh umur perusahaan terhadap kinerja perusahaan. Jadi penambahan umur perusahaan harus diimbangi dengan peningkatan tata kelola berkelanjutan.

\section{E. Simpulan dan Saran}

Penelitian ini bertujuan untuk mempelajari faktor - faktor yang dapat mempengaruhi kinerja keuangan pada perusahaan perbankan yang terdaftar di Bursa Efek Indonesia (BEI) dengan menggunakan sampel sebanyak 12 perusahaan untuk periode tahun 2011 - 2016. Berdasarkan hasil analisis dan pembahasan yang telah dilakukan dengan menggunakan regresi linear berganda, maka diperoleh kesimpulan sebagai berikut: 
1. Kas operasi terbukti tidak berpengaruh signifikan terhadap laba perusahaan.

2. Ukuran perusahaan terbukti tidak berpengaruh signifikan terhadap laba perusahaan.

3. Umur perusahaan berpengaruh signifikan terhadap laba, namun dengan tanda yang berubah. Artinya bahwa semakin tinggi umur perusahaan, maka akan semakin rendah laba perusahaan.

Berdasarkan simpulan tersebut di atas, maka disarankan hal-hal sebagai berikut :

1. Perusahaan perbankan tidak dapat hanya bergantung pada arus kas operasinya, tetapi harus terus mencari dana-dana baru dari nasabahnya untuk mencapai laba yang semakin meningkat.

2. Perusahaan perbankan harus terus meningkatkan tatakelolanya karena ternyata besarnya perusahaan perbankan dan lama umur perusahaan tidak menjamin peningkatan laba perusahaan.

\section{F. Daftar Pustaka}

\section{Buku}

Mulford, Charles W., Comiskey, Eugene E. Creative Cash Flow Reporting: Uncovering Sustainable Financial Performance. John Wiley \& Sons, Inc., Hoboken, New Jersey, 2005.

Subramanyam, K. R. dan John J. Wild. 2013. Analisis Laporan Keuangan. Edisi 10. Buku Dua. Dialihbahasakan oleh Dewi Yanti. Jakarta: Salemba Empat.

\section{Jurnal}

Amato, Louis H. Burson, Charlotte Timothy E. The Effects Of Firm Size On Profit Rates InThe Financial Services. Journal of Economics and Economic Education Research, Volume 8, Number 1, 2007.

Chang, Chia Lin. Hsu, Hui Kuang. McAleer, Michael. Is Small Beautiful? Size Effects of Volatility Spillovers for Firm Performance and Exchange Rates In Tourism. North American Journal of Finance and Economics, 2013.

Dogan, Mesut. Does Firm Size Affect The Firm Profitability? Evidence From Turkey. Research Journal of Finance and Accounting, Vol. 4, No. 4, 2013.

Gaur, Vishal. , Saravanan Kesavan. The Effects of Firm Size and Sales Growth Rate on Inventory Turnover Performance in the U.S. Retail Sector. 1 Johnson Graduate School of Management, Cornell University, 2007.

Ghozali, Imam, Ratmono, Dwi. Analisis Multivariat dan Ekonometrika: Teori, Konsep, dan Aplikasi Dengan Eviews 8. Universitas Diponegoro Semarang, 2013.

Ilaboya, Ofuan J., Ohiokha, Izien. F. 2016. Firm Age, Size and Profitability Dynamics: A Test of Learning by Doing and Structural Inertia Hypotheses. Business and Management Research Vol. 5, No. 1, 2016. 
Jensen, MC, Meckling, Wiliam H.. 1976. Theory of the Firm: Managerial Behavior, Agency Cost and Ownership Structure. Journal of Financial Economics. Vol.3.No.04

Kroes, James R., Manikas, Andrew S. 2014. Cash flow management and manufacturing firm financial performance: A longitudinal perspective. Int. J. Production Economics, Elsevier.

Kurshev, Alexander. Strebulaev, Ilya A. Firm Size and Capital Structure. Graduate School of Business Stanford University, 2005.

Leite, Rodrigo, Carvalhal, Andre. 2016. Firm age, value, performance and corporate governance in brazil. Corporate Ownership and Control, Volume 13 Issue 4 September 2016.

Loderer, Claudio. Waelchli, URS. 2010. Firm age and performance. University of Bern, ECGI European Corporate Governance

Luo, Mei. 2008. Unusual operating cash flows and stock returns. J. Account. Public Policy 27 (2008) 420-429.

Michalski, Grzegorz. 2015. Agency Costs in Small and Medium Wood Industry Enterprises with Full Operating Cycle and Cash Levels. Procedia Economics and Finance 34 ( 2015 ) $461-468$.

Mun, Sung Gyun, Jang, See Cheong (Shawn). 2015. Working Capital, Cash Holding, and profitability of restaurant firm. International Journal of Hospitality Management.

Muslih, Mochamad, Amin, Nuryatno. 2018. The Influence of Audit Opinion to The Company Stock Price. International Seminar and Call for Paper, Accounting Study Program S1, Faculty of Economics, Pamulang University, and Indonesian Accounting Association of KAPD Banten.

Ni, Yensen, Huang, Paoyu, Chiang, Pinhui, Liaoc, Yulu. 2019. Cash flow statements and firm value: Evidence from Taiwan. The Quarterly Review of Economics and Finance.

Pomar, Juan Nunes. Gasco, Vicente Prado. Sanz, Vicente Ano. Hervas, Josep, Crespo. Moreno, Ferran Callabuig. Does Size Matter? Entrepreneurial Orientation and Performance in Spanish Sport Firms. Journal of Business Research, 2016.

Rohmawati, Yuni, Suhikmat. 2017. Pengaruh Arus Kas Operasi Dan Hutang Jangka Panjang Terhadap Laba Usaha (Studi Kasus Pt. Unilever Tbk). Jurnal Akuntansi Fakultas Ekonomi Universitas Borobudur, Volume 11 No. 1 April 2017.

Rossi, Matteo. The impact of age on firm performance: a literature review. Corporate Ownership \& Control / Volume 13, Issue 2, Winter 2016.

Selcuk, Elif Akben. 2016. Does firm age affect profitability? Evidence from turkey. International Journal of Economic Sciences.

Sunarti, Adi, Sulaeman. Pengaruh arus kas operasi terhadap pertumbuhan laba perusahaan: Studi kasus pada PT Multi Manunggal. Jurnal Ilmiah Ranggagading, volume 11 nomor 2, Oktober, 2011.

Wenas, Deisy Debora, Manossoh, Hendrik, Tirayoh, Victorina Z. 2017. Analisis pengaruh arus kas operasi dan laba bersih terhadap dividen kas pada perusahaan properti yang terdaftar di Bursa Efek Indonesia (BEI). Jurnal EMBA Universitas Sam Ratulangi, Fakultas Ekonomi dan Bisnis Vol.5 No.1 Maret 2017, Hal. 96 - 104.

Yisau Abiodun, Babalola. The Effect of Firm Size on Firms Profitability in Nigeria. Journal of Economics and Sustainable Development Vol.4, No.5, 2013. 